\title{
PRZEDSIĘBIORCZOŚĆ JAKO KONIECZNY CZYNNIK SPÓJNOŚCI
}

\begin{abstract}
Streszczenie
Spójność jest jednym z najczęściej używanych i eksploatowanych pojęć w terminologii Unii Europejskiej, zaś jej podnoszenie jest głównym zadaniem Unii Europejskiej co najmniej od czterdziestu lat. Niestety, dotychczasowe doświadczenia kreowania i realizowania polityki spójności pokazuja jej ograniczoną skuteczność. Autor niniejszego artykułu formułuje hipotezę, iż powodem tej niskiej skuteczności była dominacja celów politycznych nad ekonomicznymi. Wydaje się, iż pożądaną zmianę priorytetów polityki spójności wprowadza strategia „Europa 2020”, która podnosi rolę zarządzania gospodarczego sprzyjającego rozwojowi przedsiębiorczości.
\end{abstract}

Słowa kluczowe: spójność, polityka spójności, przedsiębiorczość, strategia „Europa 2020”, Semestr Europejski

\section{ENTERPRENEURSHIP AS NECESSARY FACTOR OF COHESION}

\section{Summary}

Cohesion is one of the most commonly used and exploited concepts in the terminology of the European Union, and raising the subject has been the EU's main task for at least forty years. Unfortunately, the attempts to create and implement an efficient cohesion policy have so far proved to be of limited success. The author of the paper proposes a hypothesis that the reason for this low effectiveness is the dominance of political objectives over economic ones. It seems that the desired change of cohesion policy priorities is introduced by the Europe 2020 Strategy, which emphasises that the role of economic governance is conducive to the development of entrepreneurship.

Key words: cohesion, cohesion policy, entrepreneurship, "Europe 2020" Strategy, European semester

JEL classification: F53, L26. P11

\section{Wstęp}

Od czasu Jednolitego Aktu Europejskiego spójność jest jednym z najczęściej używanych i eksploatowanych pojęć w terminologii Unii Europejskiej. Generalnie, definiowanie i rozumienie spójności nie budzi specjalnych kontrowersji, chociaż w literaturze można 
spotkać cały zestaw różnych koncepcji. Na przykład najczęściej uważa się, że wzrost spójności gospodarczej polega (sprowadza się do) na zmniejszeniu zróżnicowań w poziomie rozwoju gospodarczego między obszarami bogatymi a biednymi. Z kolei, spójność społeczna jest mierzona za pomocą wskaźnika stopy bezrobocia, ale coraz częściej jako miernik uwzględnia się stope partycypacji (miernik określający, jaka część ludności w wieku produkcyjnym znajduje zatrudnienie). Wzrost spójności społecznej polega na zmniejszaniu zróżnicowań w wykorzystaniu kapitału ludzkiego pomiędzy poszczególnymi obszarami [Ryszkiewicz, 2013, s. 30-31] ${ }^{1}$.

Natomiast zadaniem Unii Europejskiej jest podwyższanie poziomu spójności: gospodarczej, społecznej i terytorialnej (przestrzennej). Traktatowe usankcjonowanie tego zadania (polityki spójności) nastapiło za sprawą wprowadzenia do Traktatu ustanawiajacego Europejska W spólnote Gospodarczq nowego V tytułu, poświęconego spójności gospodarczej i społecznej [Ryszkiewicz, 2013, s. 19]2². Trzeci wymiar spójności (spójność terytorialna) został uwzględniony w podpisanym w Rzymie, w dniu 29 października 2004 roku, Traktacie ustanawiajacym Konstytucje dla Europy.

Blisko czterdziestoletnie doświadczenia kreowania polityki spójności pokazuja jej ograniczoną skuteczność. Dowodzą także, iż długofalowe działania władz publicznych ewoluowały, poszukując skuteczniejszego wzorca rozwoju gospodarczego i społecznego w regionach. Skutki bywały różne. Stąd celem niniejszego artykułu jest ocena dotychczasowej skuteczności unijnej polityki spójności oraz próba wskazania przyczyn ograniczonej skuteczności tej polityki, a jednocześnie zaproponowania pewnych kierunków nowych preferencji. Autor formułuje hipotezę główna, którą stanowi stwierdzenie, iż warunkiem koniecznym poprawy skuteczności polityki spójności jest uwzględnianie w większym stopniu, jako preferowanych obszarów tej aktywności, przedsiębiorczości.

\section{Idea spójności i jej realizacja}

Polityka spójności to jedna z polityk unijnych, która ma na celu niwelowanie dysproporcji w poziomie rozwoju regionów w krajach członkowskich. W szczególny sposób jest skierowana w stronę regionów najsłabiej rozwiniętych, na przykład peryferyjnych regionów rolniczych bądź regionów zurbanizowanych dotkniętych różnego rodzaju zjawiskami kryzysowymi. Polityka spójności, wywiedziona ze strategicznych dokumentów

1 Koncepcja spójności gospodarczej nie budziła wątpliwości w literaturze przedmiotu, natomiast rozumienie spójności społecznej, bliskie pojmowaniu europejskiego modelu społeczeństwa, sprawia trudności w operacjonalizacji tego pojęcia, na co zwróciła uwagę Komisja Europejska, stwierdzając: Co sie tycay spójności społecznej, jest znacznie trudniej zdefiniowá́ ja w operacyjnym wyrażeniu. Punketem wyjścia mogłoby być połaczenie spójności społecznej z celami europejskiego modelu społeczeństwa, który jest zbudowany na pojęciu spotecznej gospodarki rynkowej [Ryszkiewicz, 2013, s. 31-30].

2 Nastąpiło to dzięki Jednolitemu Aktowi Europejskiemu, który podpisano 17 lutego 1986 roku w Luksemburgu i 28 lutego 1986 roku w Hadze, który wszedł w życie 1 lipca 1987 roku. W tytule tym, w artykule 130a, zostało zapisane: W celu wspierania swego harmonijnego rozwoju W spólnota rozwija i prowadzi działania zmierzajace do wzmocnienia swej spójności gospodarczej i spotecznej. W szczególności W spólnota zmierza do zmniejsz̨enia dysproporcji w poziomach rozwoju różnych regionów oraz zmniejszania zacofania regionón mniej upraywilejowanych [Ryszkiewicz, 2013, s. 19]. 
Unii Europejskiej (przede wszystkim Odnowionej Strategii Lizbońskiej oraz Odnowionej Strategii Zrównoważonego Rozwoju), koncentruje się na trzech celach, tj.: konwergencji (spójności), podniesieniu konkurencyjności i zatrudnienia oraz europejskiej współpracy regionalnej [Wódz, Klimek, 2016, s. 15].

\section{Główne cele europejskiej polityki spójności}

RYSUNEK 1.

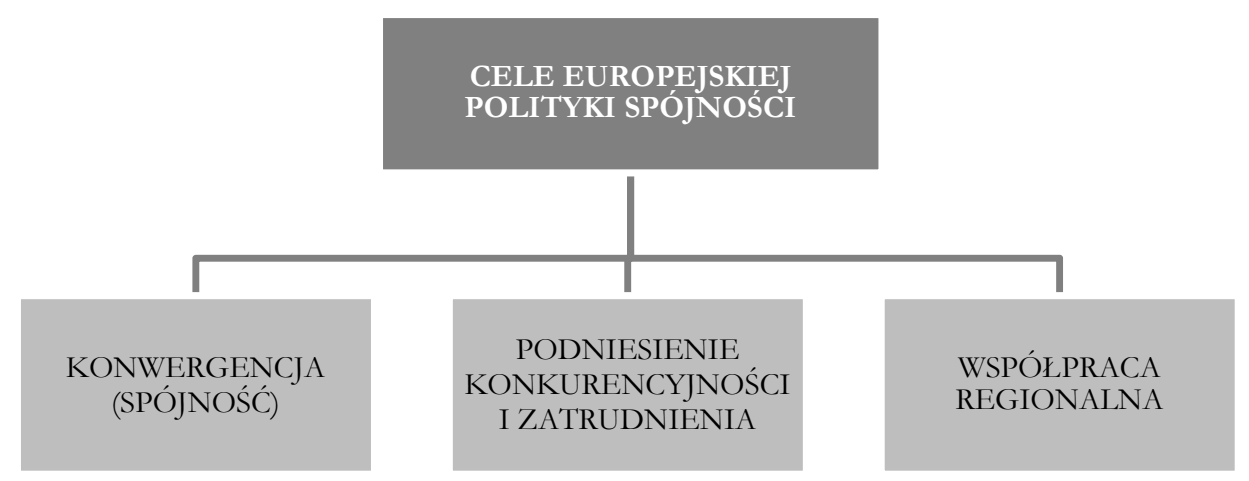

Źródło: [Wódz, Klimek, 2016, s. 15].

Próbując podsumować różne uzasadnienia polityki spójności (niewątpliwie takie funkcjonowały w oficjalnych dokumentach Unii Europejskiej i w literaturze), należy zauważyć, że jednym z mocniejszych było przekonanie, że rynek jako mechanizm alokacji zasobów nie wystarcza do osiagnięcia spójności, potrzebna jest więc interwencja publiczna pozwalająca na uzyskanie równowagi rozwojowej między regionami. Jednak wydaje się, że cały projekt został zdominowany przez zestaw celów politycznych, wśród których oficjalnie najczęściej formułowano:

- promowanie integracji Unii Europejskiej w celu zapobieżenia znacznej migracji pracowników do bardziej rozwiniętych części Unii Europejskiej, co mogłoby prowadzić do poważnych problemów ekonomicznych i społecznych w obszarach emigracji;

- promowanie stabilności gospodarczej i społecznej dzięki łagodzeniu wpływu zewnętrznych szoków na lokalne dochody i zatrudnienie;

- $\quad$ pomoc w konsolidacji jednolitego rynku przez zapewnienie, że ci, którzy zyskuja mniej na jego powstaniu, uzyskają kompensatę od tych, którzy zyskują najwięcej, gdyż w przypadku takiej kompensaty słabsze regiony mogłyby powrócić do pytania o korzyści ekonomiczne i społeczne z integracji [Wnorowski, 2013, s. 140-141].

W konsekwencji można stwierdzić, iż fundusze unijne pozwalają nadrabiać dystans w stosunku do najbogatszych, ale w różnych regionach przynoszą rozmaite efekty. Za dowód takiej właśnie tezy przyjmuje się fakt utrzymujących się ciagle dramatycznych 
różnic w poziomach deficytów oraz długu publicznego w poszczególnych krajach członkowskich (patrz: np. tabela 1.).

TABELA 1.

Saldo i dług sektora instytucji rządowych i samorządowych

\begin{tabular}{|c|c|c|c|c|c|c|c|c|}
\hline \multirow[b]{2}{*}{ GEO/TIME } & \multicolumn{4}{|c|}{$\begin{array}{c}\text { Saldo sektora general } \\
\text { government }\end{array}$} & \multicolumn{4}{|c|}{$\begin{array}{l}\text { Dług publiczny sektora } \\
\text { general government }\end{array}$} \\
\hline & 2012 & 2013 & 2014 & 2015 & 2012 & 2013 & 2014 & 2015 \\
\hline UE (28 krajów) & $-4,2$ & $-3,3$ & $-3,0$ & $-2,4$ & 83,7 & 85,6 & 86,5 & 84,5 \\
\hline Strefa Euro (19 krajów) & $-3,6$ & $-3,0$ & $-2,6$ & $-2,1$ & 89,4 & 91,3 & 91,8 & 89,9 \\
\hline Belgia & $-4,2$ & $-3,1$ & $-3,1$ & $-2,5$ & 104,3 & 105,5 & 106,8 & 106 \\
\hline Bułgaria & $-0,3$ & $-0,4$ & $-5,5$ & $-1,6$ & 16,7 & 17 & 27 & 26 \\
\hline Czechy & $-3,9$ & $-1,2$ & $-1,9$ & $-0,6$ & 44,5 & 44,9 & 42,2 & 40 \\
\hline Dania & $-3,5$ & $-1,2$ & 1,1 & $-1,8$ & 44,9 & 44 & 44 & 39,5 \\
\hline Niemcy & 0,0 & $-0,1$ & 0,3 & 0,6 & 79,8 & 77,4 & 74,6 & 70,9 \\
\hline Estonia & $-0,3$ & $-0,2$ & 0,7 & 0,1 & 9,7 & 10,2 & 10,7 & 10 \\
\hline Irlandia & $-8,0$ & $-6,1$ & $-3,6$ & $-1,9$ & 119,6 & 119,4 & 104,5 & 76,9 \\
\hline Grecja & $-8,9$ & $-13,2$ & $-3,6$ & $-5,7$ & 159,6 & 177,4 & 179 & 176,8 \\
\hline Hiszpania & $-10,5$ & $-7,0$ & $-6,0$ & $-5,3$ & 85,7 & 95,5 & 100,4 & 99,4 \\
\hline Francja & $-4,8$ & $-4,1$ & $-3,9$ & $-3,6$ & 89,6 & 92,4 & 95 & 95,8 \\
\hline Chorwacja & $-5,2$ & $-5,3$ & $-5,1$ & $-3,3$ & 70,6 & 81,7 & 85,8 & 85,4 \\
\hline Włochy & $-2,9$ & $-2,9$ & $-3,0$ & $-2,6$ & 123,4 & 129 & 131,8 & 131,5 \\
\hline Cypr & $-5,6$ & $-5,1$ & $-8,8$ & $-1,2$ & 79,7 & 102,6 & 107,5 & 107,5 \\
\hline Lotwa & $-1,2$ & $-1,0$ & $-1,2$ & $-1,2$ & 41,2 & 39 & 40,9 & 36,9 \\
\hline Litwa & $-3,1$ & $-2,6$ & $-0,6$ & $-0,2$ & 39,8 & 38,8 & 40,5 & 42,6 \\
\hline Luksemburg & 0,3 & 1,0 & 1,3 & 1,4 & 22 & 23,7 & 22,7 & 22 \\
\hline Węgry & $-2,4$ & $-2,6$ & $-2,7$ & $-2,0$ & 77,6 & 76 & 75,2 & 74,7 \\
\hline Malta & $-3,5$ & $-2,4$ & $-1,8$ & $-1,1$ & 67,8 & 68,4 & 63,8 & 60,3 \\
\hline Holandia & $-3,9$ & $-2,4$ & $-2,3$ & $-2,1$ & 66,3 & 67,8 & 68 & 64,6 \\
\hline Austria & $-2,2$ & $-2,0$ & $-2,7$ & $-1,0$ & 81,7 & 81 & 83,8 & 84,3 \\
\hline Polska & $-3,7$ & $-4,1$ & $-3,6$ & $-2,6$ & 53,7 & 55,7 & 50,2 & 51,1 \\
\hline Portugalia & $-5,7$ & $-4,8$ & $-7,2$ & $-4,4$ & 126,2 & 129 & 130,6 & 128,8 \\
\hline Rumunia & $-3,7$ & $-2,1$ & $-1,4$ & $-0,8$ & 37,3 & 37,8 & 39,4 & 37,9 \\
\hline Słowenia & $-4,0$ & $-14,7$ & $-5,3$ & $-2,9$ & 53,8 & 70,4 & 80,3 & 82,6 \\
\hline Słowacja & $-4,3$ & $-2,7$ & $-2,7$ & $-2,7$ & 52,2 & 54,7 & 53,5 & 52,3 \\
\hline Finlandia & $-2,2$ & $-2,6$ & $-3,2$ & $-2,7$ & 53,9 & 56,5 & 60,2 & 63,6 \\
\hline Szwecja & $-1,0$ & $-1,4$ & $-1,6$ & 0,2 & 38,1 & 40,8 & 45,5 & 44,2 \\
\hline Wielka Brytania & $-8,2$ & $-5,4$ & $-5,5$ & $-4,3$ & 84,5 & 85,6 & 87,4 & 88,2 \\
\hline Norwegia & 13,8 & 10,8 & 8,7 & 5,7 & 29,1 & 29,7 & 27,3 & 31,6 \\
\hline
\end{tabular}

Źródło: Eurostat (kod pobrania: tec00127 i tsdde410).

Takie fakty w sposób naturalny skłaniają do sformułowania pytania o przyczyny zróżnicowanej skuteczności polityki spójności Unii Europejskiej. W ocenie autora, 
jednym z wyjaśnień może być teza Talebaßs: Wspótczesny swiat chce, jak to tylko możliwe, uyeliminować wsželka zmienność. Stabilizujemy cykle koniunkturalne, stabilizujemy dochód w ciagu ¿jycia, a nawet stabilizujemy temperature swojego ciata, biorac leki przecinngoraczkowe (chcemy zrónnoważonego rozwoju). Ale eliminowanie zmienności w ręeczywistości osłabia ludri, firmy i całe gospodarki. Zmienność jest represjonowana, rysylko ukrywane pod dywan, ale w końcu wybucha z cata moca. Wtedy wszyscy bolesnie przekonija sie, ze sytuacja wcale nie była stabilna, tyllko krucha. No prawie wssyscy, zuyjatkiem tych, ketórsy byli za to odpowiedzialni, bo to oni driataja wedtug zasady: «Wssysstho, co dobre to moja zustuga, nic, co žte nie jest moja winq» [Taleb, 2013]. Wydaje się, że tak sformułowane opinie można w pewnej mierze odnieść do polityki spójności.

Po drugie, trendy z ostatniej dekady wyraźnie pokazują, że szczególnie szybko rozwijaja się regiony $z$ dobrze prosperującymi gałęziami przemysłu bądź licznymi inwestycjami w działalność przemysłowa, a przede wszystkim obszary aglomeracyjne i położone wokół największych miast.

Zarówno teşy Taleba, jak i wspomniane wyżej fakty autor tego artykułu traktuje jako dowód prymatu przedsiębiorczości nad spójnością. Innymi słowy, formułuje tezę, iż nie ma spójności bez przedsiębiorczości. Co wydaje się zasadnicze, iż nawet Unia Europejska na etapie prac nad strategia „Europa 2020” zdała sobie sprawę, że konieczny jest właśnie skuteczny mechanizm kreowania, wdrażania i monitorowania zachowań przedsiębiorczych. Strategia ta określa wizję społecznej gospodarki rynkowej dla Europy w XXI wieku i obejmuje trzy wzajemnie ze soba powiązane priorytety, a mianowicie:

- rozwój inteligentny - rozwój gospodarki opartej na wiedzy i innowacji;

- rozwój zrównoważony - wspieranie gospodarki efektywniej korzystającej z zasobów, bardziej przyjaznej środowisku i bardziej konkurencyjnej;

- $\quad$ rozwój sprzyjający włączeniu społecznemu - wspieranie gospodarki o wysokim poziomie zatrudnienia, zapewniającej spójność społecznąi terytorialną [Ryszkiewicz, 2013, s. 82].

Dlatego wraz z przyjęciem tej strategii zainicjowano prace nad wzmocnieniem zarządzania gospodarczego, tak aby osiagnąc lepsze uwzględnienie wymiaru europejskiego w planowaniu krajowych strategii gospodarczych oraz zapewnienie środków na realizacje celów strategii w budżetach państw członkowskich.

Ważnym składnikiem tego procesu było ustanowienie tzw. Semestru Europejskiego, tj. okresu obejmującego zasadniczo pierwszych sześć miesięcy każdego roku, w którym dokonuje się oceny i koordynacji polityki gospodarczej w celu włączenia polityki: budżetowej, makroekonomicznej i strukturalnej państw członkowskich w cykl planowania na

3 Nassim Nicholas Taleb nie jest typowym intelektualistą. Urodził się w Libanie w arystokratycznej rodzinie i odebrał znakomite wykształcenie na zachodnich uczelniach (University of Paris, Wharton School, University of Pennsylvania). Większą część swojej kariery zawodowej spędził na parkiecie nowojorskiej giełdy jako trader instrumentami pochodnymi. Na dwa lata przed kryzysem w 2006 roku odszedł z rynku kapitałowego. Dziś, oprócz tego, że pisze książki, jest profesorem zarządzania ryzykiem m.in. na New York University's Polytechnic Institute. Słowem, jest to prawdziwy filozof żyjący zgodnie z pryncypiami, które głosi i nie waha się nadstawiać karku dla swoich często ,niepoprawnych" poglądów [Taleb, 2013]. 
szczeblu Unii Europejskiej. Zasadniczym założeniem Semestru Europejskiego jest synchronizacja procesów aktualizacji Krajowych Programów Reform (przygotowywanych w ramach strategii „Europa 2020”) oraz programów stabilności lub konwergencji (przygotowywanych w ramach Paktu stabilności $i$ wzrrostut ${ }^{4}$ ) Zaleta zaś to, że pojawiają się zalecenia dotyczące ułatwień dla przedsiębiorczości na poziomie mikro.

Na przykład Komisja Europejska w listopadzie 2016 roku przedstawiła państwom członkowskim strefy euro podjęcie, indywidualnie i zbiorowo, w latach 2017-2018 poniższych działań:

1. Prowadzenie polityk wspierających wzrost gospodarczy w perspektywie krótko- i długoterminowej oraz poprawiających zdolności dostosowawcze, przywrócenie równowagi i konwergencję. Priorytetowe traktowanie reform zwiększających wydajność, usprawniających otoczenie instytucjonalne i biznesowe, usuwających utrudnienia dla inwestycji oraz wspierających tworzenie miejsc pracy $(\ldots)$.

2. Prowadzenie ogólnie pozytywnego kursu polityki budżetowej, który przyczynia się do zrównoważonej kombinacji polityki budżetowej i monetarnej, aby wspierać reformy i wzmacniać ożywienie gospodarcze za pomocą ekspansji budżetowej na poziomie do $0,5 \%$ PKB w 2017 roku.

3. Wdrożenie reform promujących: konkurencyjność, tworzenie miejsc pracy, wysoka jakość miejsc pracy, odporność oraz gospodarczą i społeczna (...) konwergencję (...), na podstawie efektywnego dialogu społecznego. Reformy te powinny łączyć między innymi (...): (iv) nowoczesne, trwałe $\mathrm{i}$ adekwatne systemy zabezpieczenia społecznego, które skutecznie i wydajnie przyczyniają się przez cały cykl życia do włączenia społecznego i do integracji na rynku pracy. Zmniejszanie opodatkowania pracy, zwłaszcza w przypadku osób o niskich dochodach oraz w państwach członkowskich, w których konkurencyjność kosztowa pozostaje w tyle za średnią strefy euro, a także zapewnienie neutralności budżetowej opodatkowania pracy w państwach, w których brakuje marginesu swobody budżetowej (...) [http://data.consilium.europa.eu/doc/ document/ ST-15070-2016-INIT/pl/PDF].

\section{Znaczenie aktywności gospodarczej na poziomie mikroekonomicznym}

Kluczem do zrozumienia dynamiki procesu rozwoju ekonomicznego jest poznanie sensu działań człowieka. Arystoteles twierdził, że: (...) ludzie podejmuja driałania celowe, bo taka jest natura dziatań ludzkich. Trudno uyobrazic sobie istoty ludzkie, które nie pragna doprowadzic do poprawy swoich warunków sycia [Arystoteles, 2007]. Twierdzenie to jest aksjomatem: prakseologii, ekonomii i socjologii. Człowiek podejmuje działania po to, by zaspokoić przede wszystkim potrzeby niezbędne do życia, a następnie także potrzeby wyższego

\footnotetext{
4 Programy stabilności przygotowują państwa członkowskie strefy euro, natomiast programy konwe-
} rgencji przygotowują pozostałe państwa członkowskie Unii Europejskiej. 
rzędu. Zmierza do zmiany obecnego stanu rzeczy na nowy, który uznaje za bardziej zadowalający. Nieustannie dokonuje wyboru zarówno pomiędzy różnymi alternatywnymi celami, środkami, jak i sposobami ich realizacji. Rezygnuje z jednych dóbr po to, by osiagnąc inne, lepiej zaspokajające jego potrzeby [Papaj, 2010, s. 31-34]5.

Dla ekonomistów kluczowa jest aktywność człowieka w ramach przedsiębiorstwa, gdyż to, co dzieje się właśnie w przedsiębiorstwach, decyduje o sukcesie lub jego braku w procesie rozwoju gospodarczego. Z jednej strony niska ich konkurencyjność może zagrozić makroekonomicznej stabilizacji gospodarki, z drugiej zaś strony, im bardziej efektywna jest polityka makroekonomiczna, tym większa jest presja na przedsiębiorstwa wywołana aprecjacją waluty krajowej i z kolei tym bardziej prawdopodobne jest ryzyko zachwiania wzrostu gospodarczego. Przedsiębiorstwa odgrywają także zasadniczą rolę w procesie stabilizacji gospodarki, zmierzającym do tłumienia inflacji i stabilizacji cen [Wnorowski, 2014, s. 257].

Jak genialnie zauważył Edward Lipiński, przedsiębiorstwo to jeden z najważniejszych wynalazków cywilizacyjnych i wciąż stanowi podstawę gospodarki, pozwalającą na tworzenie bogactwa narodów i uczestnictwo ludzi w tym tworzeniu. Zjawisko udanego i nieudanego zakładania przedsiębiorstw pasjonuje praktyków i teoretyków od chwili jego powstania. Tradycyjne pytania: dlaczego powstają przedsiębiorstwa w ogóle, dlaczego te, a nie inne, w tych, a nie innych gałęziach, dlaczego te, a nie inne rozwijają się, dlaczego tak wiele kończy swój żywot przez upadłość, wydaje się, że szczególnie dzisiaj wymagają nowej odpowiedzi [Noga, 2009, s. 18].

W procesie poszukiwania tych $\mathrm{i}$ innych odpowiedzi warto odwołać się do pojęcia przedsiębiorczości. Bez przedsiębiorczości nie ma wszak dobrze funkcjonujących, a co najważniejsze, nie ma nowych przedsiębiorstw. To przecież przedsiębiorczość przyczynia się do generowania: nowych technologii, produktów i usług, które spychają do lamusa swoich poprzedników. Prowadzi to z jednej strony do upadku, a z drugiej do powstawania całych branż. W ten sposób przedsiębiorczość napędza rozwój cywilizacji.

Pierwsze sformułowania przedsiębiorczości były wyprowadzane z funkcji realizowanych przez przedsiębiorcę. J. Schumpeter, powołując się na J.B. Saya, stwierdził, iż funkcją przedsiębiorcy jest kombinowanie czynników produkcji. Jest to przy tym działalność specjalnego rodzaju, gdy czynniki te zostają połączone po raz pierwszy, łączenie

5 Cztowiek opisywany przez. Ludwiga von Misesa jest jednostka racjonalna. Wssyscy ludzie musza driałać. Resygnacja zpodjecia aktywności, zaniechanie badź kierowanie sie popedami jest tak:że driataniem, tak samo jak uypowiedzenie

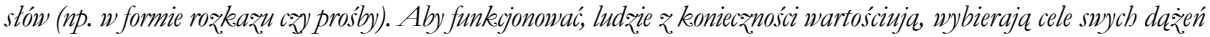

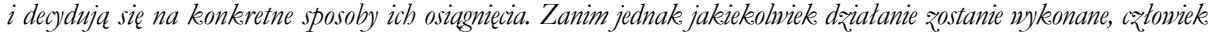
musi przejśc tray poprzedzajace etapy. Pierwssym jest zaistnienie dyskomfortu, čzyli niepożadanego stanu rzeçy. Bez zaistnienia dyskomfortu żadne działanie nie zostanie podjete, gdy $\mathbf{w}$ warunkach petnego spetnienia jakakolwiek zmiana stanu mogtaby jedynie pogorssyć sytuacje podmiotu. (...) Aby działanie zostało uykenane, musi pojawić sie ponadto przekonanie, że celowe zachowanie jednostki mo:ze choć do pewnego stopnia zaspokoić potrzebe (zredukować dyskomfort). (...) Ostateczna decyzja, aby zadziatać, będrie wiazała sie z kalkulacja cry mysitek, jakim jest wstanie z bamaka, warty jest mniej niž nieprzyjemnośc zwiazana z doswiadczeniem uporcyywego brzeczenia. Warto pamietać o decydujacej roli przekenania jednostki o wtasnej sprawczości $i$ zdolności cžtowieka do abstrakcyjnego myślenia - jeśli prayczyne

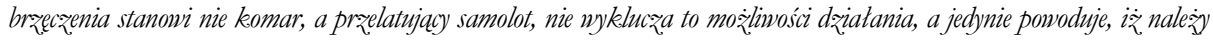
zastosować inne środki redukecji dyskomfortu - w tym praypadku moga to być stopery ograniczajace hatas [Papaj, 2010, s. 31-34]. 
ich w trakcie prowadzenia przedsiębiorstwa jest jedynie zwykłą rutyną. Przedsiębiorczość w jego pojęciu obejmuje pięć następujących przypadków:

- wprowadzenie nowego towaru, $z$ jakim konsumenci nie są jeszcze obeznani, lub nowego gatunku towaru;

- $\quad$ wdrożenie nowej metody produkcji;

- $\quad$ otwarcie nowego rynku;

- $\quad$ zdobycie nowego źródła surowców lub półfabrykatów;

- przeprowadzenie nowej organizacji przemysłu, np. stworzenie sytuacji monopolistycznej lub złamanie pozycji monopolistycznej.

Z punktu widzenia szkoły austriackiej podstawowym przedmiotem jej zainteresowania nie jest jednak to, kto dokładnie wykazuje się przedsiębiorczością (chociaż praktycznie jest to najważniejsza kwestia), ale to, że z powodu braku instytucjonalnych czy prawnych ograniczeń wolnej przedsiębiorczości każda osoba ma swobodę jej praktykowania, jak również tworzenia nowej informacji i wykorzystywania praktycznej, wyłącznej wiedzy, którą odkryła w danych okolicznościach [Huerta, 2010, s. 39-40].

Jeśli z jakiejkolwiek przyczyny pole dla przedsiębiorczości w określonej dziedzinie życia społecznego jest ograniczone lub zamknięte (w wyniku regulacji prawnych, instytucjonalnych czy tradycji lub interwencjonistycznych środków narzuconych przez państwo), ludzie nie będą nawet brać pod uwagę możliwości osiagnięcia celów w tych zakazanych obszarach, zatem, skoro cel nie jest możliwy, nie będzie on służył jako bodziec, a w konsekwencji jednostka nie dostrzeże ani nie odkryje praktycznej wiedzy potrzebnej do jej osiagnięcia. Co więcej, i co gorsza, w takich warunkach nawet bezpośrednio tym dotknięte osoby nie będą świadome ogromnej wartości i liczby celów, które nie będą mogły być osiagnięte ze względu na instytucjonalne ograniczenia [Huerta, 2010, s. 39-40].

\section{Podsumowanie}

Unia Europejska wskazuje (wymaga od swoich krajów członkowskich) w końcu potrzebę aktywnych zachowań w obszarze przedsiębiorczości. Przykładem takiej determinacji Unii Europejskiej jest nowa strategia gospodarcza na rzecz inteligentnego i zrównoważonego rozwoju sprzyjającego włączeniu społecznemu pod nazwa „Europa 2020”.

Od 2010 roku Komisja Europejska, silniej niż wcześniej, stawia na inteligentny, zrównoważony wzrost gospodarczy przeciwdziałający wykluczeniu społecznemu. Nowa strategia przekłada się na ambitne cele stawiane państwom członkowskim. Dotyczą one: zwiększania zatrudnienia i produktywności, zmniejszania liczby osób o niskich kwalifikacjach oraz wzrostu gospodarczego [Styczyńska, 2015].

Tworzenie nowych przedsiębiorstw oznacza przyrost zdolności wytwórczych na rynku oraz generuje następujące efekty odnoszące się do strony podażowej:

- $\quad$ wymusza efektywność działania firm istniejących;

- przyspiesza zmiany strukturalne w wyniku procesu „kreatywnej destrukcji”;

- intensyfikuje innowacyjność za sprawą tworzenia rynku przez nowe firmy; 
- $\quad$ zwiększa różnorodność produktów i metod rozwiązywania problemów, co powoduje większe prawdopodobieństwo zaspokojenia preferencji konsumentów.

Te wpływy procesów tworzenia przedsiębiorstw moga prowadzić do poprawy konkurencyjności gospodarki, przemysłu lub regionu, a zatem przyczyniać się także do podnoszenia spójności.

\section{Literatura}

Arystoteles, 2007, Etyka nikomachejska, Wydawnictwo Naukowe PWN, Warszawa. http://data.consilium.europa.eu/doc/document/ST-15070-2016-INIT/pl/pdf (data wejścia: 12.09.2017).

Huerta de Soto J., 2010, SZkoła austriacka. Lad rynkowy, wolna nymiana i przedsiębiorczość, Wydawnictwo Fijorr Publishing, Warszawa.

Noga A., 2009, Teorie przeedsiebiorstw, Państwowe Wydawnictwo Ekonomiczne, Warszawa.

Papaj L., 2010, Koncepcja cžtowieka w pracach Ludwiga von Milesa, Wydawnictwo PROHIBITA, Warszawa.

Ryszkiewicz A., 2013, Od konwergencii do spójności i efektywności. Podstany teoretyczne polityki spójności gospodarczej, społecznej i terytorialnej Unii Europejskiej, Oficyna Wydawnicza Szkoły Głównej Handlowej, Warszawa.

Styczyńska I., 2015, Czas obniżyć koszty pracy, „Rzeczpospolita”, 05.03.2015.

Taleb N., 2013, Antykruchość. O rzeczach, którym stużq wstrzasy, Wydawnictwo Kurhaus, Warszawa.

Wnorowski H., 2014, Przedsiębiorczość jako element kadu gospodarczego, [w:] Lad gospodarçyy a wspótczesna ekonomia, P. Pysz, A. Grabska, M. Moszyński (red.), Wydawnictwo Naukowe PWN Warszawa.

Wnorowski H., 2013, Spójność versus przedsiębiorczosí́ jako droga realizacji ambicij rozwojomych, [w:] Fundusze europejskie w polityce spójności, A. Augustyn, H. Ostapowicz (red.), Wydawnictwo Uniwersytetu w Białymstoku, Białystok.

Wódz K., Klimek M., 2016, Koncepcja spójności społecznej w Unii Europejskiej, [w:] Zarzqdranie spójnościa społeczna: globalne wirjje i lokalnepraktyki, M. Witkowski, K. Wódz (red.), Wydawnictwo Naukowe Wyższej Szkoły Biznesu w Dąbrowie Górniczej, Dąbrowa Górnicza. 